\title{
Personal income tax structure in Nepal: An evaluation
}

\author{
Jit Bahadur K.C. ${ }^{1}$ Anant Lal Karn ${ }^{2}$ Ph.D. \\ 1. Ph.D. Scholar, Mewar University, Grangrar, Chittorgarh (RJ), India \\ 2. Research Supervisor, Professor, Tribhuvan University, Nepal \\ Corresponding Author \\ Jit Bahadur K.C. \\ E-mail: managementtu14@gmail.com
}

\begin{abstract}
Purpose - This paper aims to evaluate the structure of the PIT in Nepal.

Methodology/design/approach -This study adopts descriptive and quantitative research approach, sourcing the data and information from both primary and secondary, which include books, reports (economic survey, report/statement of Central Bureau of Statistics, etc.), journals, bulletins, newspapers, websites, etc. For the objective result, we use statistical tools to confirm the value of the PIT structure.
\end{abstract}

Findings and conclusion - The PIT is a major ingredient of income tax, which contains a complex and critical structure in income components, exemption limit, tax base, units, and tax rates. The study found increment in the exemption limit based on equity, equality and with the rate of inflation. However, the method of determination of exemption limit was unscientific. The tax slabs and rates observed three categories progressive, degressive and mild progressive under the three governments regimes inconsistent with national tax policy. Different era of government imposed the tax burden on different slabs and observed decline in tax progressivity in the later year. In the studied period, the PIT payers sacrificed $27.81 \%$ amount as tax and saved only $72.19 \%$ of their total taxable net earnings. It showed a high rate of tax. The tax burden on PIT reached as high as $45.49 \%$ in 1989-90 and as low as $24.13 \%$ in 1998-99. The gap between maximum and minimum ranged $22.89 \%$, with a great disparity in the tax policy and an average tax, the burden remained $32.56 \%$ during the studied period. A high rate of tax encourages the evasion; taxpayers alter their decisions on the financial activities, which reduce the benefit of both the public authorities and taxpayers or citizens. Good tax policy should strive to provide benefit to both the concerned parties.

Originality/value - This is descriptive research to find out the structure of PIT in Nepal, which is derived and written by the author using the primary as well as secondary sources of data and information. Thus, this is original writing in the context of Nepal and in PIT literature.

Keywords - Inclusions, deduction, exemption, taxpayer unit, tax base, tax slab tax rate, tax burden. 


\section{Introductory background}

The government has to perform some core duties and responsibilities towards its citizens. Consequently, it needs a huge amount of fund to perform those functions. Dalton (1948) viewed that to maintain and equip the armed forces, to rule out the administration of justice and maintenance of the ceremonial head of the State, Court and of diplomatic representatives abroad are foremost important functions. Similarly, to maintain the machinery of civil government, to pay public debt charges, to pay expenditure that directly devoted to fostering industry and commerce and to pay social expenditure on health, education, old age pensions, poor relief, provision for unemployment, etc. are also functions of a government. With the purpose of performing those functions and to meet the cost and expenses, governments manage their funds from different sources (i.e., taxes, fees, prices and other sources -gifts, fines, penalties and grants-in-aid (Andley \& Sundharam, 1989).

Among the above-stated sources, the taxes are the most important due to them being compulsory levy. Therefore, governments prefer to raise the tax revenue by levying on the three objects (i.e., income, capital and expense) to attain the five objectives: economic development by generating revenue, control inflation, control of cyclical fluctuations, full employment, reduction of the balance of payment difficulties and reduce income inequalities.

Fundamentally, taxes can be classified into two categories (i.e., direct and indirect) based on the place of payment. Dalton (1948) viewed these taxes in the following words:

A direct tax is really paid by a person on whom it is legally imposed, while an indirect tax is imposed on one person, but paid partly or wholly by another, owing to consequential change in the terms of some contract or bargaining between them. (p. 33)

Personal income tax (PIT) is a constituent of the direct tax and includes the three heads of income (i.e., business -sole proprietor, employment and investment), which emerge through factors of production like labour plus capital, labour and capital respectively of economics. However, according to the income tax of Nepal, it does not include the exempted income and income of final withholding payments.

According to the revenue objectives of taxation, PIT is a backbone of the revenue generation in both developed and developing economies where it plays a considerable role like a centrepiece in the tax system (Haan, 2007) because most of the developed and developing economies raise their significant shares of tax revenue from PIT. Moreover, most of the countries applied the progressive rate of tax to levy the PIT. Consequently, it justifies both horizontal and vertical equity and an ability-to-pay principle of a good tax system.

The theory of PIT includes several items of taxable income from income and capital gain other than items of corporate income tax. Thus, PIT is a complex tax in the structure of income taxation. Masui and Nakazato (2000) viewed that the PIT structure grounds on three fundamental components: base, unit and rate. These components of PIT structure are directly associated with the tax yield, which the government collects annually.

There is a framework for the taxable base of the PIT, which is obtained after deduction of exemption on income tax provided to the units of taxpayers (i.e., individual and couple or family). Similarly, the tax base is multiplied by the tax rate to obtain the tax liability. Thus, this study aims to analyse the structure of PIT to inquire and acquire new knowledge in order to add to the literature in the field of income taxation.

\section{Issues and problems}

Nepal is one of the least developed countries in the world. The experts of development and progress argue that there are several constraints (i.e., geographic, political, economic, educational, cultural, infrastructural, technological, etc.), which hinder the development of Nepal.

Nepal has been suffering from a huge fiscal gap since the very beginning; however, it completed in nearly 14 periodic plans. There are several weaknesses in revenue sectors. The contribution of direct tax in terms of the tax revenue in a percentage is very low as compared to other developing countries while PIT 
Vol. 4, No. 1

is a major component of the direct tax.

Table 1

Position of Nepal and its neighbouring countries

\begin{tabular}{lcccccccc}
\hline Countries & $\begin{array}{c}\text { Total tax } \\
\text { revenue to }^{\text {GDP ratio }}{ }^{(1)}\end{array}$ & Rank & $\begin{array}{c}\text { Budget } \\
\text { Deficit in } \\
\text { \% of GDP }\end{array}$ & Rank & $\begin{array}{c}\text { Per Capita } \\
\text { Nominal } \\
\text { in USD }^{(1)}\end{array}$ & Rank & $\begin{array}{c}\text { Income } \\
\text { inequality } \\
\text { (Gini) }^{(1)}\end{array}$ & Rank \\
\hline Afghanistan & 7.58 & 9 & -22.1 & 9 & 550 & 9 & 27.8 & 1 \\
Bangladesh & 8.76 & 8 & -4.9 & 6 & 1,517 & 7 & 32.0 & 3 \\
Bhutan & 13.12 & 3 & -5.4 & 7 & 3,130 & 4 & 38.7 & 7 \\
China & 9.15 & 6 & -4.0 & 3 & 8,827 & 2 & 42.2 & 9 \\
India & 8.79 & 7 & -6.9 & 8 & 1,942 & 5 & 35.1 & 5 \\
Maldives & 19.46 & 2 & -3.7 & 2 & 11,151 & 1 & 36.8 & 6 \\
Nepal & 20.95 & 1 & -0.1 & 1 & 849 & 8 & 32.8 & 4 \\
Pakistan & 9.18 & 5 & -4.5 & 4 & 1,548 & 6 & 30.7 & 2 \\
Sri Lanka & 11.6 & 4 & -4.8 & 5 & 4,074 & 3 & 39.8 & 8 \\
\hline
\end{tabular}

Source: ${ }^{1}$ The World Bank (2017)

According to the above-stated indicators, the economic status of Nepal is weak in every aspect. The evidence showed that total tax revenue to gross domestic product (GDP) ratio of Nepal is the highest in the region. It means that either Nepal produces only a small amount of goods and services or it imposes and collects a high rate of tax to or from its citizens. Similarly, the budget deficit of Nepal is the lowest in the region, as it's budget deficit is only $0.1 \%$ of the GDP.

Nepal ranks eighth and fourth position in per capita GDP and income inequality respectively, among its eight neighbouring countries, which facts stimulate to think about the economic growth and development of Nepal. In this case, we claim that income tax is a vehicle of the economic growth and PIT is a major component of the income taxation but complex system among the taxes. Thus, we conducted this study of the structure of PIT to inquire and acquire new knowledge to suggest an appropriate and better tax structure to earn adequate income tax revenue to make our nation prosper.

\section{Objectives of the study}

In light of the foregoing discussion, the present study focuses on the following objectives:

- $\quad$ To measure the structure of PIT in Nepal.

- $\quad$ To ascertain the income tax burden of PIT.

- $\quad$ To suggest further improvement on the structure.

\section{Study variables}

Research is a systematic investigation in order to establish facts for new knowledge. It crucially involves certain variables. Accordingly, this study includes the following research variables to investigate their relationship:

- Tax revenues: investment, employment and business — sole proprietor tax revenue of the resident natural person

- $\quad$ GDP deflator

- $\quad$ PIT base

- $\quad$ PIT units

- $\quad$ PIT rates. 


\section{Scope and limitations of the study}

This study covers the PIT and its structure in Nepal from the fiscal year 1975-76 (1976) to 201718 (2018). The knowledge about the structure of PIT is considerably important to the researchers, scholars, professors, teachers, students, professionals, businesspersons and so on. This study limits its area on highlighting of provisions, the framework of the calculation of the tax base, and analysis as well as exploration on the structure based on taxpayers unit, tax base and the tax rate to obtain the new knowledge. Financial resources, available of the literature and timeframe were the main constraints in the study.

\section{Theoretical framework and literature review}

This section is the epitomic version of the existing literature. Thus, it succinctly highlights the basic concept of the existing theoretical literature and previous research and discussion for the further improvement of the literature to obtain the knowledge gap in the existing research.

\section{Concept of income and taxation}

In a broad sense, the concept of income substantially differs from the concept of receipts. The former denotes the amount of money received over a period of time either as payment for work, goods, or services or as profit on a capital only, while the latter denotes the amount of money or goods received either as income or as any refundable amount in the future. Thus, in this context, the opinion of Dalton (1948) is still notable:

The income of a public authority may be defined in either a broad or a narrow sense. In the broad sense, it includes all 'incomings' or 'receipts', in the narrow sense, only those receipts which are included in the ordinary conception of 'revenue'. ... The chief elements included in the conception of public receipts, but excluded from that of public revenue, are receipts from public borrowings and from the sale of public assets.... (p. 25).

Thus, the government receipts may be either revenues or only receipts.

The government revenue is a combination of tax and non-tax revenue. The former is a compulsory charge imposed by a public authority, but the latter is voluntary. In Taussig's view (as quoted in (Dalton, 1948), "The essence of a tax, as distinguished from other charges by Government is the absence of a direct quid pro quo between the taxpayer and the public authority" (p. 26). Taxation is the main source of government revenue. It is a more reliable, flexible and easy source of revenue compared to other sources of income or receipts of the government.

The governments mobilize both internal and external resources. The former includes revenue receipts (tax and non-tax) and net capital receipts while the latter includes loans and grants from foreign governments for the purpose of capital and development expenditure. To attain the rapid growth of an economy, external resource mobilization is a sine-qua-non, but in the opinion of Samuel (n.d.), most of the countries mobilize the bulk of their resources for development internally rather than externally. There is a crucial difference between internal and external resource mobilization, not only in the origin but also in the application of the resource in question. The internal resources are more appropriate to meet domestic developmental needs.

External sources of receipts or revenues include all amounts of money received by a government, originating from outside the government, net of refunds and other correcting transactions proceeds from the issuance of debt, the sale of investments, agency or private trust transactions and intergovernmental transfers. Normally, both the receipts: grants and loans may be either bilateral or multilateral.

In the case of Nepal, the government receipts include four major sources: tax revenues, non-tax revenues, grants and loans. Among the said sources, the first three fulfil the features of revenue, but the last one falls under the category of receipt. The receipts from both the bilateral and multilateral loans require an obligation to refund (including interest) in a future period. All the sources cited above are common sources of receipts of all the countries, but some countries receive an additional source relating to illegal activities of revenue consisting of unreported revenue. 
Vol. 4, No. 1

In this $21^{\text {st }}$ century, taxation is widely accepted as the primary sources of state revenue, and this primacy regards to its nature of compulsion and the exaction of money without direct quid pro quo between the taxpayer and the Government. Non-tax revenue is also significant, but it requires a huge investment in the initial periods, consequently, most of the governments prefer taxation to finance their expenditures.

\section{Functions of taxation}

Taxation includes a number of functions relating to the financial and non-financial activities, but there are three major functions, referred to as the three "R": raising of revenue, resource allocation and redistribution of income. These functions of taxation connect considerably well with the objectives of taxation.

\section{Concept of PIT}

The term "concept" refers to an idea, a notion, thought, perception, impression, conception, theory, model, hypothesis, view and a belief. Therefore, the conception of PIT can be understood by the following expression:

In view of Bala, Enoch and Yakubu (2018), "Personal income tax is a tax levied on all incomes of individuals employed by a business or organization either public or private". The Cambridge Dictionary (2019) viewed that an individual tax is "A tax paid by people on the money they earn, not a tax that a company pays on its profits". The individual income tax is a synonym of the PIT. It is allowable only for resident taxpayers. Similarly, Financial Dictionary (2019) tried to convey it in a sentence, "Personal income $\ldots$ is the total annual gross earnings of an individual from all income sources, such as: salaries and wages, investment interest and dividends, employer contributions to pension plans, and rental properties".

The Revenue Department, Thailand (2019) described, "Personal Income Tax (PIT) is a direct tax levied on the income of a person. A person means an individual, an ordinary partnership, a non-juristic body of a person and an undivided estate". The PIT does not include the income of the corporate body.

There exist two models for the structure of PIT: scheduler and global. In view of Burns and Krever (1998), "A scheduler income tax is one in which separate taxes are imposed on different categories of income. A global income tax is one in which a single tax is imposed on all income, whatever its nature" (p. 1).

Thus, PIT in Nepal can be justified by the definition of the Cambridge Dictionary (i.e., A tax paid by people on the money they earn, not a tax that a company pays on its profits) and global model of income tax.

\section{Framework for calculation of PIT}

Tax is a compulsory financial charge levied by the government on either income or expense or capital or any transaction without direct quid pro quo between the payer and receiver.

PIT includes the individual's income tax sourced from business, employment and investment. Thus, in the calculation framework of the PIT requires the calculation of each head included and deduction therefrom separately to obtain the assessable income from each head.

There are nine items of deduction in business income while there are only five for the investment income and there is no deduction under the head of the employment income. The general deductions include several items of expenses based on the three rules of thumb: (i) expenses incurred during the year, (ii) expenses incurred by the person, and (iii) expenses incurred for receiving or earning of income (Income tax Act, 1974) \& (Income tax Act, 2002). The first rule states that the expenses claimed for deduction must relate to earning the income presented during the year. The second rule states that the taxpayers (be it an individual or an entity) must incur the expense. Similarly, the third rule states that the expenses must be associated with the receiving or earning of the claimed income (the incurred expense must not be associated with the exempt or final withheld income) (K.C., 2016). 
NCC JDURNAL - 2019

After obtaining the assessable income from each head, it requires sum of these heads in order to deduct the retirement payment and donation and to get the taxable income (but not taxable base) for the PIT. The whole framework of the PIT regards as given below:

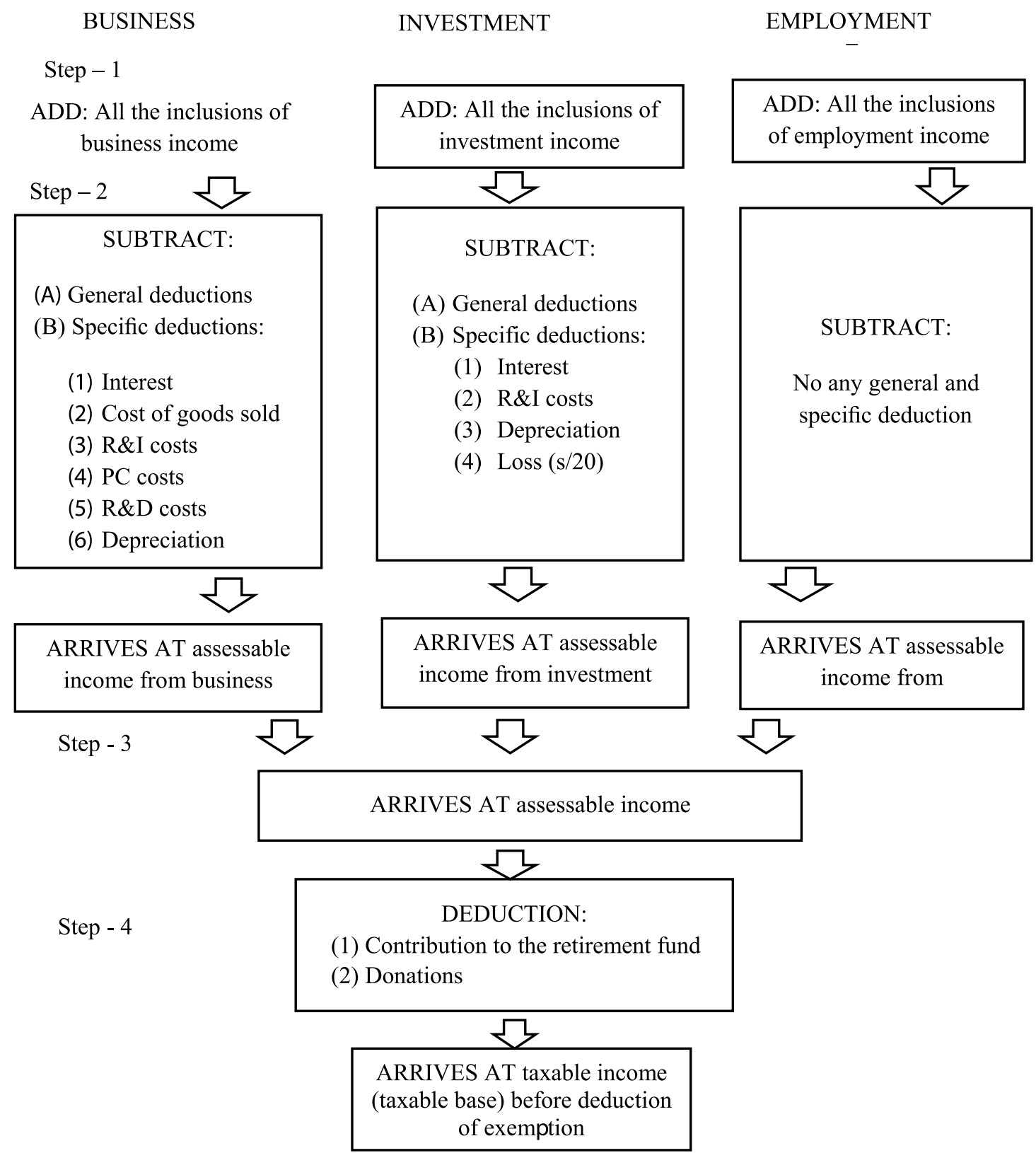

Figure 1. Framework for calculation of PIT

Amount of income on which tax is actually charged or the amount of income from which tax losses, personal allowances and other relieve must be deducted before arriving at the amount to which the tax rates are applied. Taxable income is the assessable income less deductions for retirement contribution and gifts to the exempt organization (Income tax Act, 2002).

In the calculation of the taxable income of the PIT, first assessable incomes of those three heads (i.e., employment, business and investment) are to aggregate in sum for the income year. Then, to obtain the taxable income, we should reduce the gifts to exempt organization and certain contributions to approved $\sim 74 \sim$ 
Vol. 4, No. 1

retirement funds for the year.

According to the convention of tax law, the taxable base is the amount on which the tax rate is applied to obtain the tax liability. The taxable base is a bottom-line amount, taking into consideration all possible deductions, losses and personal allowances.

Taxable income differs from the tax base for the individual natural person, but it does not differ in the case of income of an entity. In the case of an entity, taxable income and taxable base remain the same (K.C., 2007), but in the case of individual or PIT of the resident person, it requires the following deductions:

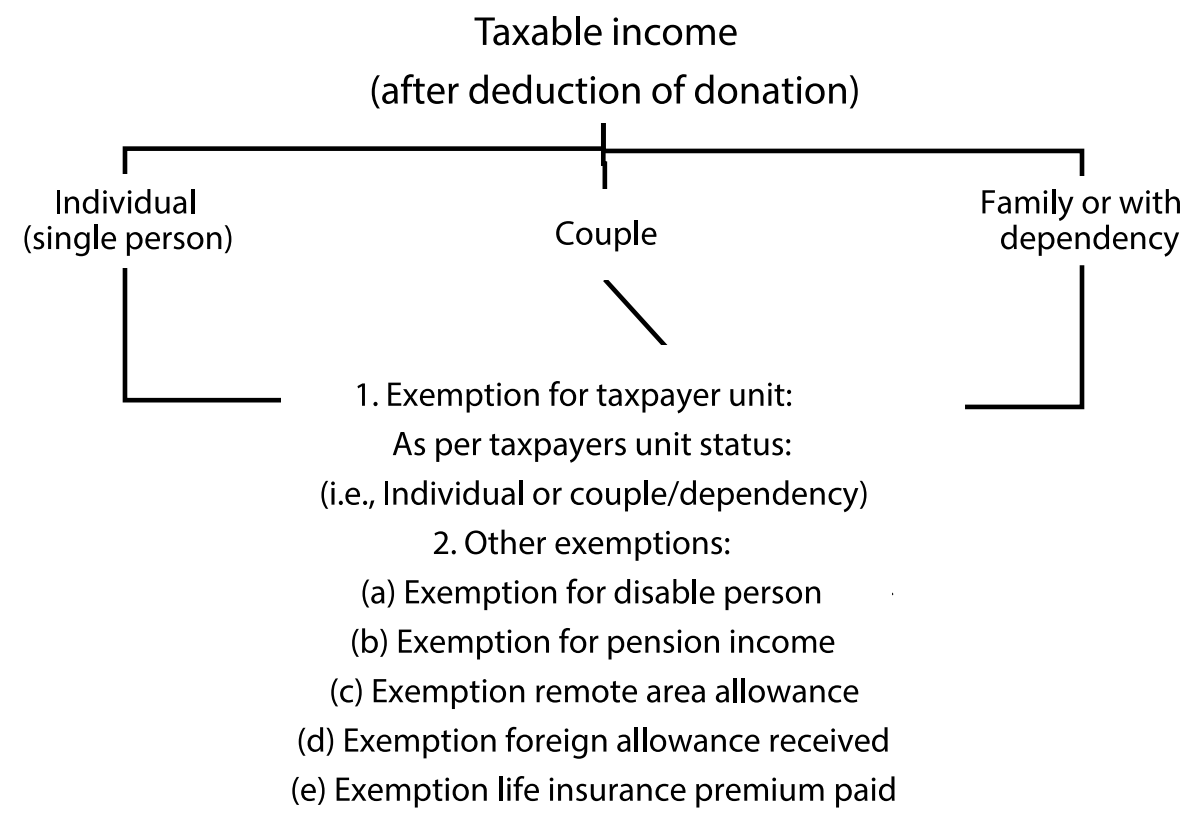

Figure 2 Exempt amounts from taxable income on PIT

Personal income exemption refers to that amount which can be deducted from an individual's total income for the purpose of reducing the taxable income (taxable base). The income tax laws of Nepal provide two (sometimes three) types of exemptions according to the family unit of the taxpayers: individual, couple, a family (dependent).

\section{Review of the previous study}

This section of the study is a succinct version of the previous research, which includes highlighted description, summary, and evaluation of each source of review. Therefore, we analysed and presented the following literature related to the entire PIT. 
Table 2

Summary of the previous studies

\begin{tabular}{|c|c|}
\hline ource & - \\
\hline Andre & $\begin{array}{l}\text { ggested to widen the deduction base of the medical expense and the charitab } \\
\text { tribution. }\end{array}$ \\
\hline Tasui and $\mathrm{N}$ & $\begin{array}{l}\text { Surveyed the fundamental theory of the three elements of PIT: (i) base, (ii) unit } \\
\text { and (c) rates and discussed the debated tax base (i.e., on which items should be } \\
\text { levied the tax), second for the units (i.e., individual, couple/family) and finally, } \\
\text { the tax rates (i.e., proportional, progressive or degressive). }\end{array}$ \\
\hline $\begin{array}{l}\text { c, Onrubia and } \\
(2004)\end{array}$ & $\begin{array}{l}\text { Studied the implication of the reformed tax comparing it with the old tax and } \\
\text { found a comparatively lower redistribution effect in the reformed PIT. }\end{array}$ \\
\hline rba & $\begin{array}{l}\text { Conducted the study to measure the level of progressivity and redistribution effect } \\
\text { of PIT and found high progressivity in Croatia compared to other countries. }\end{array}$ \\
\hline $\begin{array}{l}\text { Tran-Nam, Vu and } \\
\text { Andrew (2007) }\end{array}$ & $\begin{array}{l}\text { Conducted a simulated study of the best structure for PIT and suggested a broader } \\
\text { tax base and flatter tax rate structure according to the principle of revenue } \\
\text { neutrality. }\end{array}$ \\
\hline $\begin{array}{l}\text { Bruce, Fox and Yang } \\
\text { (2008) }\end{array}$ & $\begin{array}{l}\text { Found that a wage income tax of the state does not impact on the actual tax base, } \\
\text { but do small effect on the calculated tax base. However, wage income tax effects } \\
\text { considerably on federal aggregate income. }\end{array}$ \\
\hline $\begin{array}{l}\text { Aidt and Jensen } \\
\text { (2009) }\end{array}$ & $\begin{array}{l}\text { f the income tax in } 17 \text { Western European } \\
\text { and Japan considering the taxation as a } \\
\text { eloped world. }\end{array}$ \\
\hline ind & $\begin{array}{l}\text { istan and found that deductions } \\
\text { ls progressivity. }\end{array}$ \\
\hline $\begin{array}{l}\text { Ameer and Mohd } \\
(2012)\end{array}$ & and concluded that the \\
\hline $\begin{array}{l}\text { Binaj, Binaj and } \\
\text { Limaj (2013) }\end{array}$ & $\begin{array}{l}\text { Conducted comparative study between Albanian and American income tax systems } \\
\text { and found many similarities as well as dissimilarities. The study concluded some } \\
\text { suggestions for future tax policy for the United States of America. }\end{array}$ \\
\hline Gupt & $\begin{array}{l}\text { Evaluated the burden of tax on low and medium level people's income of India } \\
\text { and concluded that to reform the PIT structure either broadening the exemption } \\
\text { limits or lowering the tax rates, or reorganizing the different income tax slabs. The } \\
\text { study additionally suggested that to simplify the overall procedures of income } \\
\text { taxation in order to make greater compliance with the tax code. }\end{array}$ \\
\hline Szarc & $\begin{array}{l}\text { Examined the inequality of PIT structure of } 21 \text { OECD countries applying } \\
\text { regression model and found that if the PIT share of total taxation by } 1 \% \text { increases } \\
\text { the PIT rate increases only by } 0.57 \% \text {. }\end{array}$ \\
\hline $\begin{array}{l}\text { Palić, Žmuk and } \\
\text { Grofelnik (2017) }\end{array}$ & $\begin{array}{l}\text { Found that the PIT system in the Croatian economy has a significant negative } \\
\text { impact on economic growth in the long run. Taxation has a negative impact on } \\
\text { economic growth. }\end{array}$ \\
\hline
\end{tabular}


There is an entire research gap in the study of the PIT structure in Nepal. Thus, we tried to inquire about the PIT structure in Nepal for new knowledge about the context of Nepal.

\section{Methodology, methods and materials}

This section discusses the methods, tools and materials of the study. This study adopts descriptive and exploratory research according to its nature. For the purpose of the analysis of the PIT structure, we took tax exemption and tax rate data of 43 (1976 to 2018) fiscal year from different financial Acts, income tax Acts and calculated the tax burden of PIT accordingly.

We chose primary and secondary sources of data and information using books, journals, Income Tax Acts, Rules, magazines, reports (i.e., economic survey, statistical reports, salary commission report, etc.,) websites, personal information, and other related works of literature of other countries too.

We promptly took into consideration the guidelines and the views of experts in order to carry out the study. Research always adopts some procedures for producing a new and valid result. Similarly, this study assumes the following procedural stages:

- In order to determine the tax base for the PIT from 1976 to 2018, we assumed that the taxable base rupees $1,000,000$ for the fiscal year 2000-01 as a base value and we used GDP deflator to find the value of other years (i,.e., 1976 to 2018).

- We placed the value of taxable income into the required tax slabs as provided during the financial year for the respective years.

- We sum up all the tax liabilities burned by the slabs into one and we called it total tax liabilities.

- Finally, we divided the total tax liabilities by the tax base to find the tax burden for the respective fiscal year.

- We used excel and SPSS software to obtain the statistical result to justify the structure of PIT where we felt necessary.

- Composition of tax liability into different income slabs.

- Develop the tax burden trend.

\section{Results and discussion}

The purpose of this section is to interpret and describe the data of the study. Consequently, we discuss the tax base, unit and rates of the PIT system in this section. Additionally, we discuss the relationship between tax liabilities and real gross domestic product and the influence of tax liabilities on the real domestic product in the subsequent section/s.

\section{Taxpayer's unit and exemption under PIT}

Personal income exemption refers to those amounts which can be deducted from an individual's total income for the purpose of reducing the taxable income (taxable base). The income tax laws of Nepal provide two (sometimes three) types of exemption according to the family unit of the taxpayers: individual, couple, or family (dependency). At the beginning years, there were three units of the taxpayers, but when income tax Act 2002 was introduced in Nepal, the units were reduced down to two types for the resident taxpayer under the PIT system: an individual and a couple. The former denotes only an individual natural person while the latter denotes other than an individual (i.e., couple, family or a dependent individual). 


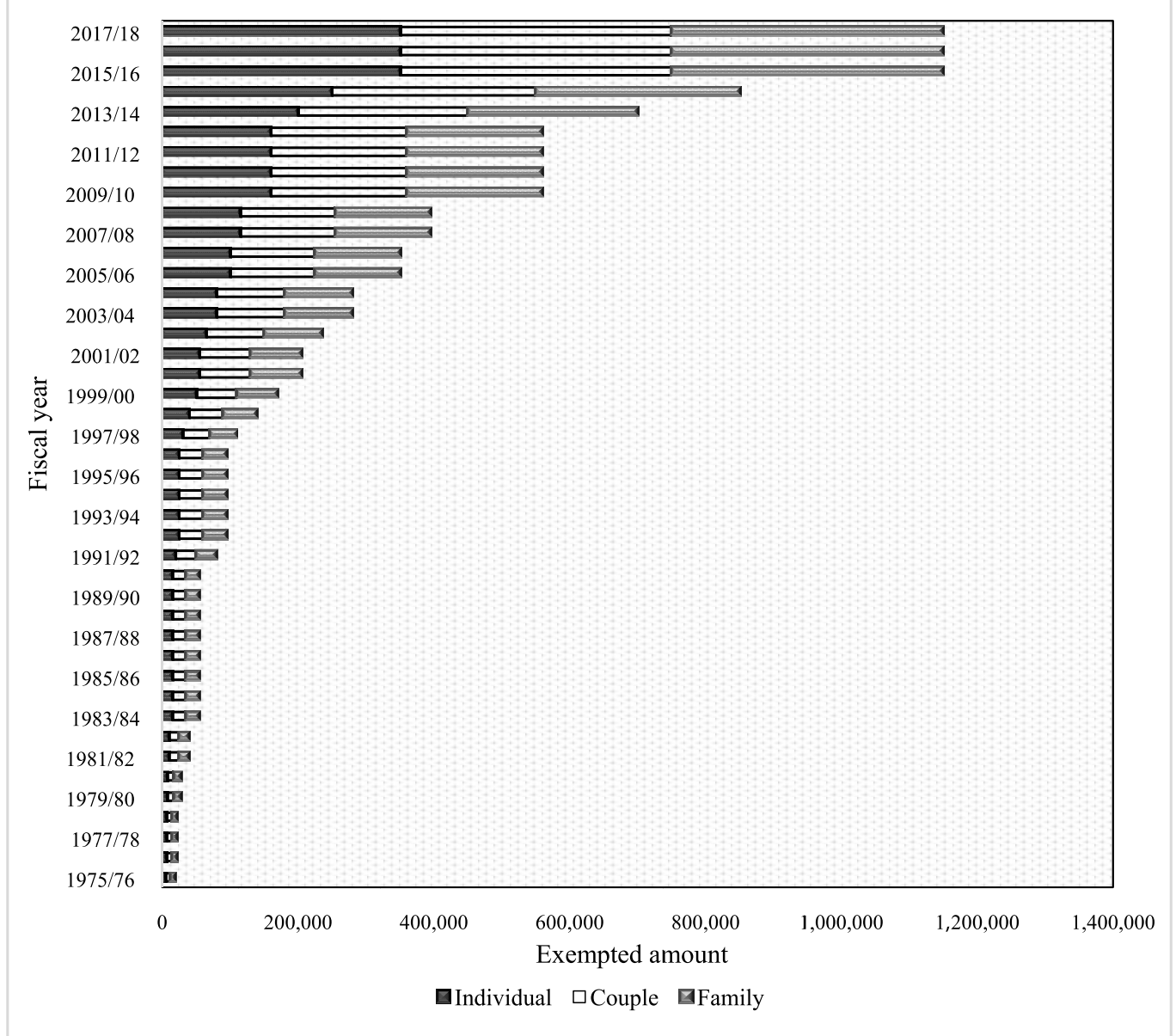

Figure 3 The exemption limit for each unit of PIT (1976 to 2018)

The above figure depicted the exemption limit of an individual, couple and family for the duration of 43 years (from 1976 to 2018) in Nepal. The study showed a gradual increment in the exemption limit with a few years of interval. The exemption limit for the unit of taxpayers changed 18 times under the reviewed period of 43 years. Similarly, the value of the exemption limit grew from nearly 53 to 67 times between 1976 and 2018.

The increment of the exemption limit between the taxpayer units (i.e., individual, couple and family) found a perfectly positive degree of association for the studied period. It means that the exemption limits for all the units of taxpayers increased based on equity and equality.

However, there is a lack of a scientific method of determination of the personal exemption. There is no clear policy or principle about the rate of the exemption limit in Nepal until date.

\section{Tax slabs in PIT}

Under this section, we discuss the tax slabs and tax rate on those slabs, which applied for the fiscal year as prescribed by the financial act. The government determines the tax rates, according to its objectives to influence the behaviour of the taxpayers.

The studied period covers three political regimes/eras such as a non-Party Panchayati system (NPS) under absolute monarchy, the democratic system under a constitutional monarchy and federal republican democratic system (FRDS). Consequently, Nepal experienced two to eight slabs tax rates under the reviewed period. The following figure highlights all the applied slabs and rates of the PIT: 


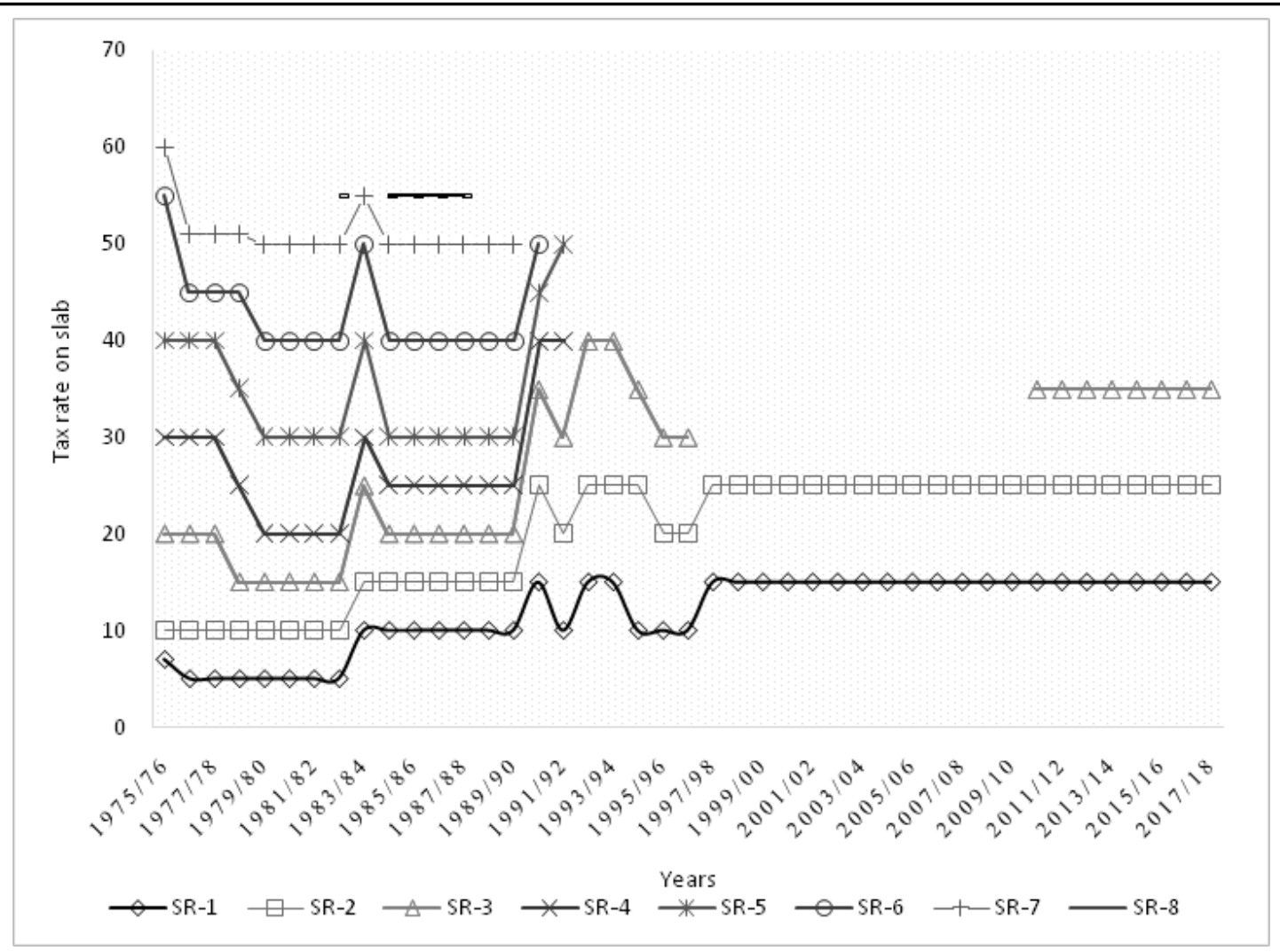

Figure 4 Tax slabs and their rates of the PIT system

Note: $\mathrm{S}=\mathrm{Slab} / \mathrm{s}, \mathrm{R}=$ rate of tax and $1,2,3 \ldots 8$ denote the number of tax slabs.

The NPS under absolute monarchy applied progressive tax rate structure. They applied seven slabbed tax rates in most of the income years during which the rates of tax were between 5 to $50 \%$, and applied eight slabbed tax rate in others, during which the rates of tax were between 5 to $60 \%$. As a result, the principle of ability-to-pay influenced the PIT system. The democratic government under the constitutional monarchy started to reduce the slabs of tax rates and reduce one slab each year after the restoration of democracy. For the income year 1992-93, the government made five slabs of tax rates and only three slabs in the following year. The government of Nepal proposed only two slabs of the tax rate for the income year 1997-98 to 200910. The tax rates were only 15 and $25 \%$. It remained so until the establishment of the FRDS government. After the establishment of the FRDS, the government applied three tax slabs tax rates in Nepal constituting 15,25 and 35 percent which are been being applied today.

The overall slab structure of the PIT concluded that it was progressive and based on ability-to-pay in the NPS under the absolute monarchy system, the degressive tax system in the democratic government under a constitutional monarchy and mild progressive in the FRDS. The resultant figures justify the inconsistency in the national tax policies and principles.

\section{Tax load on each slab in PIT}

Under this section, we discuss the tax load on the different slabs based on prescribed rates for the respective years. The study found that both the elements (i.e., the numbers of the tax slabs and rates) changed from time to time under the period of review.

In the structural analysis of the PIT, we chose analysis of a load of each slab, which can help to find out the progressivity on the PIT system in Nepal. 


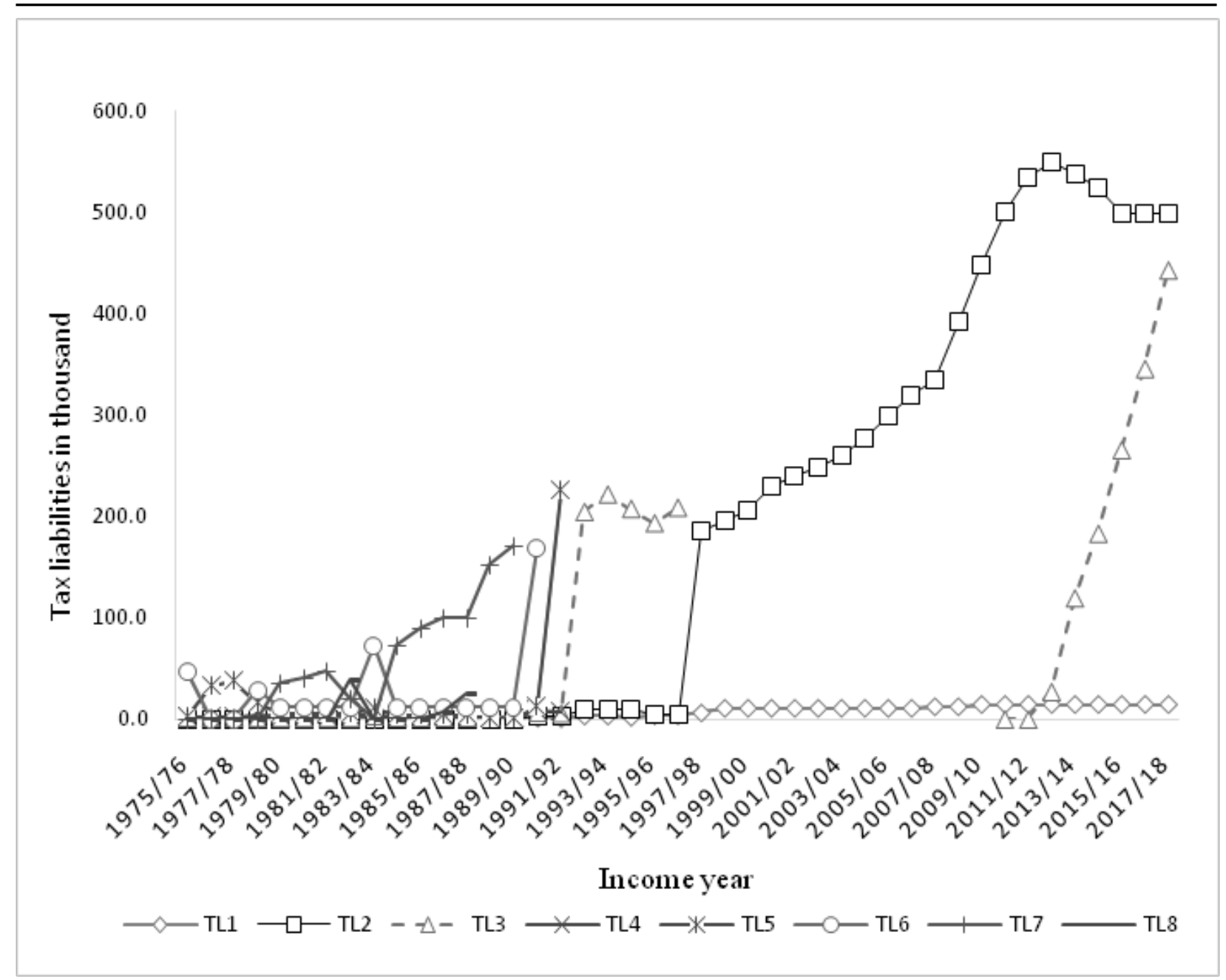

Figure 5 Income tax load on each slab of the PIT

Note: TL denotes tax liabilities and 1, 2, 3...8 denote slab numbers.

The above-stated figure revealed that the maximum tax load remained on the second slab followed by the third slab in the studied period. Similarly, the next load of the tax found on the seventh slab after that under the sixth slab. There was an insignificant tax load on the other slabs.

Evidently, the tax burden in the later slabs is better than in the beginner slabs.

\section{Total tax liabilities and taxpayers surplus after tax}

Tax liability is an amount of money payable to the government authority. In other words, the tax liability is money, which a taxpayer is to sacrifice from his earning of profit or income or capital. The taxpayer's surplus is that which the taxpayers earn after paying his tax liability. The following figure depicts the tax base, tax liability and taxpayer's portion of real owned earning. 


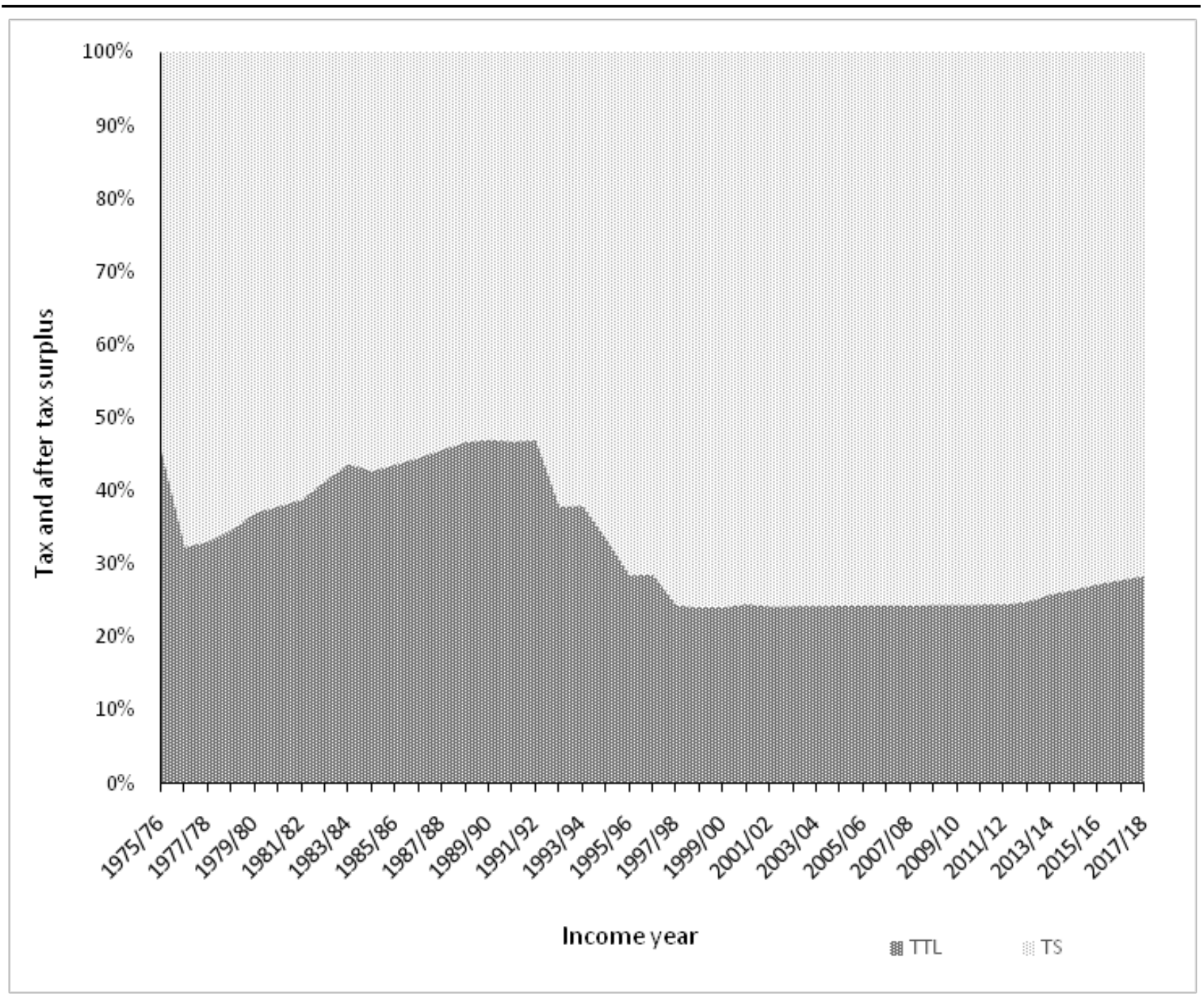

Figure 6 Segregation of the taxable income into tax and after-tax earnings on PIT

The above-depicted figure showed that the taxpayers sacrificed $45.49 \%$ and earned a surplus of $54.51 \%$ in 1976 . The sacrifice of the tax amount took an upward position and reached at the top in the history of Nepal, where taxpayer sacrificed $46.94 \%$ of the earning and made a surplus of $53.06 \%$. After the income year 1991-92, the same started to decline and became stable between 20 and $30 \%$. In totality, the PIT payers sacrificed $27.81 \%$ as tax and saved only $72.19 \%$ of their earnings during the studied period.

\section{The tax burden on PIT and its trend}

According to the Collins English Dictionary (2019), the tax burden is "The amount of tax paid by a person, company, or country in a specified period considered as a proportion of total income in that period". Economists believe that the tax burden determines the behaviour of the taxpayers. Therefore, the burden of tax is a significant study in the PIT system. Thus, we tried to analyse the trend of the tax burden for the PIT regime because, trend analysis is the technique, which helps to predict the future. 


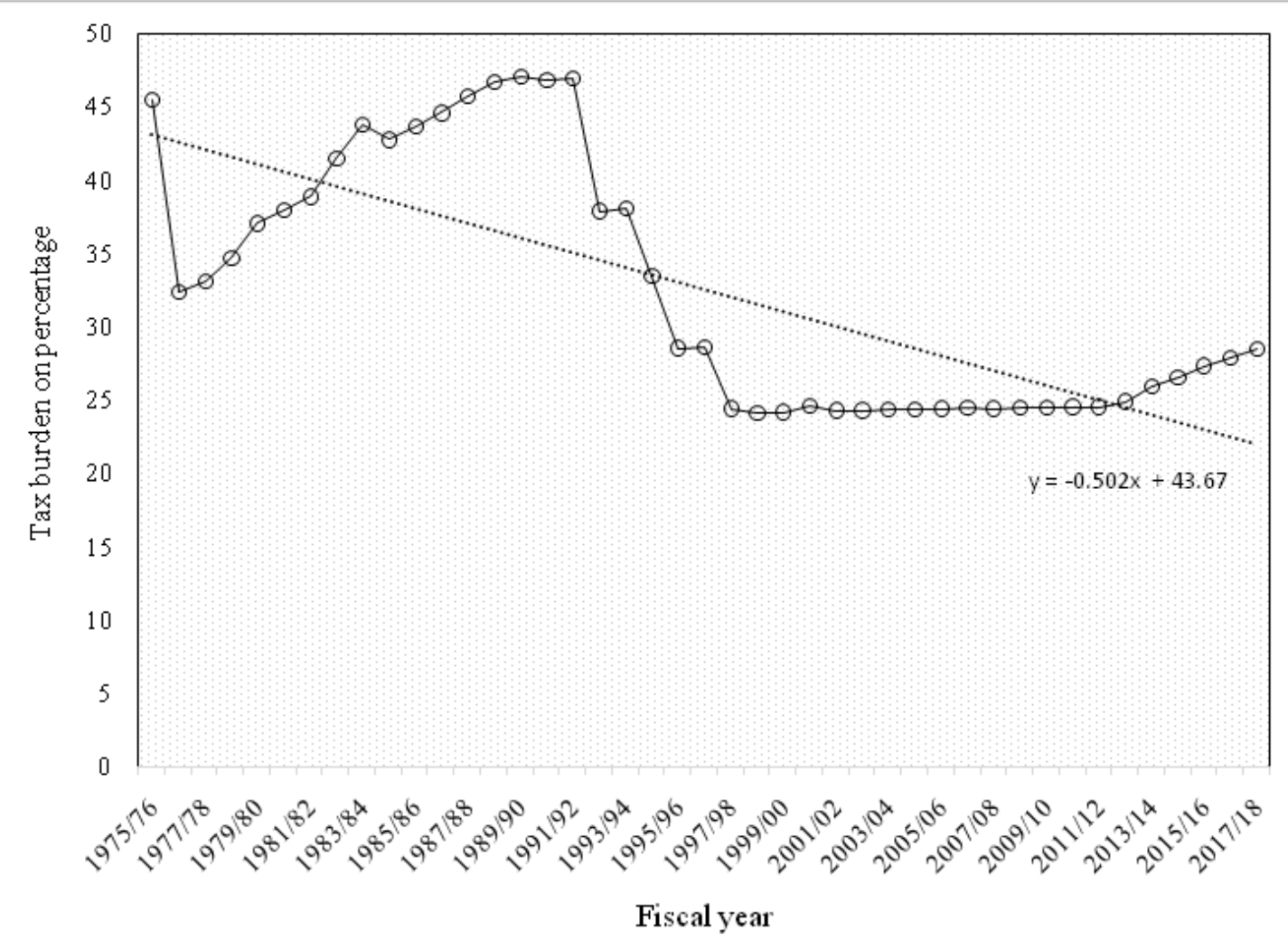

Figure 7 The trend of the income tax burden on the PIT system

The above-presented figures revealed the tax burden on PIT, the highest and the lowest of which arrived at $45.49 \%$ and $24.13 \%$ in $1989-90$ and $1998-99$ during the studied period. The gap between maximum and minimum ranged $22.89 \%$, which is a great disparity in the tax policy. Consequently, the average tax burden remained at $32.56 \%$ during the studied period.

\section{Conclusion}

Among the taxes, income tax directly influences the taxpayers and influences their decisions. In terms of time and nature, income tax is a recent innovation and is marvellously complex compared to other taxes in the tax system. The PIT is a major ingredient of income tax, which contains a complex and critical structure in income components, personal exemption limit, tax base, taxpayer units and tax rates.

The increment of the exemption limit between the taxpayer units (i.e., individual, couple and family) found perfect positive in the degree of association for the studied period. It means that the exemption limits for all the units of taxpayers increased based on equity and equality. However, there is a lack of a scientific method of determination of the personal exemption. There is no clear policy or principle for the rate of the personal exemption in Nepal to date.

The overall slab structure of the PIT concluded that it was progressive and based on ability-topay in the NPS under the absolute monarchy system, degressive in the democratic government under the constitutional monarchy and mildly progressive in the FRDS. It showed a lack of consistency in national tax policy.

The maximum tax load remained on slab two followed by slab three in the studied period. Similarly, the next load of the tax found on the slab seven thereafter under slab six. Evidently, the tax burden in the later slabs is better than in the beginner slabs.

In the studied period, the PIT payers sacrificed $27.81 \%$ amount as tax and saved only $72.19 \%$ from 
Vol. 4, No. 1

their earnings. It showed the high rate of tax.

The tax burden on PIT was $45.49 \%$ in $1989-90$ as the highest; the same was $24.13 \%$ in $1998-99$ as the lowest during the studied period. The gap between maximum and minimum ranged $22.89 \%$, which is a great disparity in the tax policy. Consequently, the average tax burden remained at $32.56 \%$ during the studied period.

Finally, the high rate on PIT encourages the evasion, discourages the payment and influences the taxpayers' decision on the financial activities; this is detrimental to both the public authorities and taxpayers or citizen. Good tax policy is one that strives to provide benefit to all the concerned sectors. Thus, we suggest that the government should make an adequate consultation with all the concerned groups of people and responsible body of the government to determine the policies and programs in order to collect adequate and justifiable tax revenue to make the nation prosper.

\section{References}

Ahmed, V., \& O'Donoghue, C. (2009). Redistributive effect of personal income taxation in Pakistan. Galway: Department of Economics, National University of Ireland.

Aidt, T. S., \& Jensen, P. S. (2009). The taxman tools up: An event history study of the introduction of the personal income tax. Journal of Public Economics, LXXXXIII(93), 160-175.

Ameer, M. W., \& Mohd, S. (2012). Personal income tax progressivity in Pakistan. IPEDR, L(26), 129-133. doi:10.7763/IPEDR

Andley, K. K., \& Sundharam, K. M. (1989). Public economics and public finance (With special reference to underdeveloped countries). Delhi: Ratan Prakashan Mandir.

Andrews, W. D. (1972). Personal deductions in an ideal income tax. Harvard Law Review, LXXXVI(2), 309-385. Retrieved from http://www.jstor.org/stable/1339894 .

Bala, A., Enoch, E. Y., \& Yakubu, S. (2018). The problems of personal income tax on revenue generation in Gombe state. International Journal of Business and Management Invention (IJBMI), VII(7), 20-28. Retrieved from www.ijbmi.org

Binaj, A., Binaj, I., \& Limaj, I. (2013). Personal income tax policy analysis: Albania vs. United States. International Journal of Economics and Financial Issues, III(1), 42-49. Retrieved from www.econjournals.com

Bruce, D., Fox, W. F., \& Yang, Z. (2008). Base mobility and state personal income taxes. Mobility and Tax Policy: Do Yesterday's Taxes Fit Tomorrow's Economy? (pp. 1-26). Tennessee: University of Tennessee.

Burns, L., \& Krever, R. (1998). Individual income tax. In V. Thuronyi (Ed.), Tax law design and drafting (Vol. II, pp. 1-67). Washington: International Monetary Fund.

Cambridge Dictionary. (2019, January 3). Individual income tax. Retrieved from Cambridge Dictionary: https://dictionary.cambridge.org/dictionary/english/individual-income-tax

Castaner, J. M., Onrubia, J., \& Paredes, R. (2004). Evaluating social welfare and redistributive effects of Spanish personal income tax reform. Applied Economics, 36, 1561-1568.

Collins English Dictionary. (2019, March 27). Definition of tax burden. Retrieved from Collins English Dictionary: https://www.collinsdictionary.com/dictionary/english/tax-burden

Dalton, H. (1948). Principles of public finance. London: Routledge \& Kegan Paul Limited. 
Financial Dictionary. (2019, March 3). Personal income. Retrieved from Financial Dictionary: https://investinganswers.com/financial-dictionary/personal-finance/personal-income-2305

Gupta, R. (2013). Personal income tax structure in India: An evaluation. Pacific Business Review International, $V(7), 1-6$.

Haan, P. (2007). The effects of personal income taxation on labor supply, employment and welfare: Empirical evidence for Germany. Berlin: An Unpublished Ph.D. Dissertation of der Freien Universit" at.

His Majesty Government of Nepal. (1974). Income tax Act. Kathmandu: Ministry of Law, Justice and Parliament Affairs.

K.C., J. B. (2007). Tax laws and tax planning: Theory and practice. Kathmandu: Khanal Book Prakashan.

K.C., J. B. (2016). Deductions for business and investment income: A discussion on income taxation. NCC Journal (A research based journal), I(1), 57-70.

Masui, Y., \& Nakazato, M. (2000). Personal income taxation. In B. Bouckaert, \& G. De Geest (Eds.), Encyclopedia of Law and Economics: Volume IV. The Economics of Public and Tax Law (pp. 139-164). USA: Edward Elgar Pub. Retrieved from https://reference.findlaw.com/ lawandeconomics/contents.html

Palić, I., Žmuk, B., \& Grofelnik, B. (2017). The long-run impact of personal income taxation on economic development: Evidence from Croatia. Croatian Review of Economic, Business and Social Statistics (CREBSS), III(1), 35-44. doi:10.1515/crebss

Szarowská, I. (2014). Personal income taxation in a context of a tax structure. Procedia Economics and Finance, XII, 662-669.

The Government of Nepal. (2002). Income tax Act. Kathmandu: Law Book Management Committee.

The Revenue Department, Thailand. (2019, January 3). Personal income tax. Retrieved from The Revenue Department, Thailand: http://www.rd.go.th/publish/6045.0.html

Tran-Nam, B., Vu, L., \& Andrew, B. (2007). Personal income tax reform in Australia: A specific proposal. Economic Analysis \& Policy, XXXVII(2), 163-186.

Urban, I. (2006). What makes the personal income tax in Croatia progressive? Newsletter - An Occasional Publication of the Institute of Public Finance(23), 1-3. 